\title{
Market Concentration And Industry Profitability: The Case Of Greek Banking (1997-2004)
}

Paraschos Maniatis, (E-mail: pman@sch.gr), Athens University of Economics and Business

\begin{abstract}
An empirical investigation of the relationship between market concentration and performance in the Greek banking, this paper finds that market concentration has a weak effect on bank profitability. This finding could be attributed to the long tradition of the Greek governments to keep the financial institutions under immediate either in the form of state-owned institutions or indirectly through a complex and rigid regulations concerning interest rates, credit standards and credit rationing.
\end{abstract}

\section{INTRODUCTION}

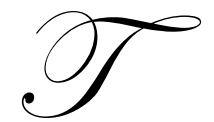

he purpose of the study is the analysis of some aspects of the Greek banking system pertaining to the performance and the degree of concentration and eventually their relation. The financial services industry, like many others today, is a multi-product industry that provides various related but differentiated products (Scott, 1999). In recent years, the industry has undergone a number of unprecedented changes that have influenced both its structure and the nature of competition within, which has forced financial institutions to change their competitive strategy. Specifically, they have become less focused on products and more focused on customers and relationships, less focused on the short term and more focused on the longer term (Harrison, 2000). Since financial institutions are vitally interested in offering high quality products, it is necessary to identify the customers' expectations and requirements as well as the level of customer satisfaction. As it concerns Banks the way services are performed may influence customers' loyalty to the Bank, and as a result Banks' competitiveness. As the level of the quality the Bank delivers is highly dependent on the customer service, it is necessary for Banks to measure the quality of services, they offer to customers (Opidowitz, 1999). Furthermore Bankers must be able to realize the needs and motivations of customers. Meeting customers' needs must be a major business strategy goal (McKechnie and Harrison, 1995). The very premise behind this study is that the integration of the Greek banking industry is still below that of the financial industries of the euro-zone. This could be attributed to the uneven development of the Greek financial institutions and the excessive market concentration and regulation that limited competition in the industry.

The remainder of the paper is in four sections. Section 1 is a review of the literature. Section 2 is an overview of the Greek banking industry. Section 3 describes the data, the methodology, and the estimation results. The fourth section concludes the discussion and explores the future structure of Greek banking industry.

\section{LITERATURE REVIEW}

Theory tells us that there is a relationship between market structure and firm performance. Namely market structures of a large number of firms will be expected to perform differently than markets with a small number of firms, especially markets controlled by a few large firms or one dominant firm. The market structure can be measured in three ways: by the number of firms in the market; by the distribution of the firms market share; and by various concentration measures (in banking the most common measures are the three and five-firm deposit or assets concentration ratio, Molyneux et al. 1996) 


\section{Market Structure And Performance In Banking}

Empirical studies of banking competition and performance are summarized in two paradigms: the StructureConduct-Performance (SCP) paradigm (Bain, 1951) and New Economic Industrial Organisation (NEIO) paradigm (Bresnahan, 1989). The SCP paradigm measures the impact of observable market or industry parameters on the conduct and performance of market participants. Early SCP studies have applied a broad range of proxies for market structure and market performance: the relationship between the buyer and the seller costs, the degree of product differentiation, the degree of concentration within a market place, the degree of market share and the entry conditions for potential new firms, for market concentration; and the relation of rates of returns to assets, the scale of the costs of selling and efficiencies for market performance. Recent studies have applied a host of other proxies, such as risk, leverage, buyer and seller concentration and foreign competition.

In principle, SCP paradigm studies reject the concept of long-term equilibrium, a link between the performance of the firm and the concentration of the market and the connection between performance and the market power of individual firms. Yet SCP paradigm studies are subject to a number of problems and limitations, most notably the reliability of high profitability as a performance proxy. A number of empirical studies have tested hypotheses in the SCP framework for depository financial institutions. Lloyd-Williams and Molyneux (1994) tested the effect of governmental and regulatory pressures upon banks to merge and the consequent effects upon market structure and conduct in a study of Spanish banks. Goldberg and Rai (1996) tested the traditional SCP hypothesis and the structure-efficiency hypothesis applying a range of performance indicators for European banks. Molyneux and Forbes (1995) tested the SCP paradigm for banks in 18 countries. The sample taken between 1986-1989 includes banks operating in a broad range of regulatory environments. The study provides empirical support for the traditional SCP paradigm concluding that the degree of concentration has an affect on the level of competition within the industry. Bourke (1989) and Berger and Hannan (1989) have been conducted other SCP banking studies. Molyneux et al (1996) have provided a review of many SCP studies. Nathan and Neave (1989) applied the Rosse-Panzar Statistic to a sample of Canadian financial institutions. Cross-sectional samples of 14 schedule A and 58 schedule B banks and 39 trust companies were considered for 1982 and 1984. Molyneux et al (1994) used the Rosse-Panzar statistic to assess competitive conditions in a number of European banking markets. This broad ranging study incorporated a number of variables to control for risk, cost and size characteristics of the institutions considered. (a result of 0.628 was estimated for the Ross-Panzar statistic) Similar results were obtained for the other European markets. Vasala (1995) applied a similar approach to assess the levels of competition in Finish banks between 1985 and 1992. Cross-sections were estimated for every year. A substantial increase in the level of contestability of Finish banking was observable over the sample period, with H statistic estimates rising from o.182 in 1995 to 0.620 in 1992 . This increase in contestability coincided with the substantial re-regulation of the Finish banking sector in 1986. Bikker and Groeneveld (1989) measured the $\mathrm{H}$ statistic for a number of European Union banking sectors. The $\mathrm{H}$ statistic is estimated for all EU banks and for individual countries, for the period 1989-96. Monopolistically competitive banking markets are reported in most European banking markets. The level of concentration appears to change only slightly over time. Spiller and Favaro (1984) tested the nature of competition of the Uruguayan banking sector, concluding that banking firms do not have the same conjectures, or respond differently to actions of other banking firms within the same market. Size was viewed to be determinant of different conjectures. Gelfand and Spiller (1987) employed a multi-product model to assess oligopolistic conditions in Uruguayan banking sector between 1977-80. It is suggested that the removal of entry barriers for foreign banks reduced the degree of oligopolistic rivalry occurring between banks and eventually led to an increase in the level of competition in the Uruguayan domestic banking market. In a one-product conjectural variation model, Shaffer (1993) confirmed the existence of perfect competition in the Canadian banking sector (1965-1989). Vesala (1995) estimated a number of models of firm conduct, including the Rosse-Panzar statistic for the Finish banking industry during the late 1980s and early 1990s. A broad range of issuers was considered, including the nature and level of oligopolistic behaviour, the measurement of price competition over time, and an analysis of the interdependence between deposit and loans market. Berg and Kim (1998) tested the oligopolistic behaviour of Norwegian banks between 1990-92 with both retail and corporate banking markets. Using a conjectural variation model it was estimated banks have significant market power in retail banking markets. Due to stronger incentives and informational advantages Norwegian banks are assumed to have far less market power in corporate banking markets. 


\section{GREEK BANKING OVERVIEW}

The banking and financial sectors have been liberalized considerably since 1987, primarily because of directives from the EU, and are now basically free of state control. Of the Greek commercial banks, the largest is the National Bank of Greece, which accounts for about one-third of the country's banking business. http://www.tradeport.org/. However, still a few of state-controlled banks as the National Bank of Greece and some specialized financial institutions together control about 71 percent of deposits and 68 percent of loans. Foreign-owned banks (including other EU-based banks) control about 9 percent of deposits and 12 percent of loans. Greek-owned private banks retain control of the remaining 20 percent of deposits and 20 percent of loans. http://www.tradeport.org/.

Furthermore, over the past few years, Greek commercial Banks have been preparing for the new highly competitive environment, that is emerging within the single banking space of EMU by strengthening their position within the domestic market, either through organic growth of their networks or through mergers and acquisitions.

\section{The Greek Banking System}

To survive and thrive in the intensification of competition brought about by deregulation and the entry of new players into the industry, Greek banks have appealed to consolidation that has created bigger players. Characteristic examples are the Piraeus Group, which emerged form the merger of Piraeus, Xiosbank and Macedonia Thrace Bank - the last one holds this moment the fifth position in the banking sector with a $7 \%$ share and 170 branch stores, and the EFG-Eurobank group, which came from the merger of Eurobank, Crete Bank, Interbank and Ergobank, taking the third position in the local market with a potential of 230 branch stores and a market share of approximately $10 \%$. However these sizes, even those of the National Bank, the biggest bank group of the country, which disposes a $20 \%$ share in the Greek market, are significantly smaller than those of the other European, competitive, financial institutions. The EFG-Eurobank group created from the merger of Eurobank, Crete Bank, Interbank and Ergobank holds the third position in the local market with a potential of 230 branch stores and a market share approximately $10 \%$. This situation sets the stage for a second stage of consolidation among Greek banks, which is expected to trigger off the transfer of clients and administrated capitals from the State to more profitable and flexible private banking groups. The sale of the Commerce Bank, whichever may be the way it happens, and the sale of shares or even majority packages of smaller national banks, such as General Bank, Attiki Bank, ETBA and Agrotiki, will signify the acquisition by banking groups, such as Alpha Credit Bank, Piraeus Bank and EFG-Eurobank, of a 20-30\% of the local banking market. In 1999, the total turnover of all listed Greek Banks was estimated at 13,2 million Euros, a significant increase from a $13 \%$ in 1998, while their profits (pretax) are estimated at 4,6 million Euros, an increase of 205\% in comparison to 1998 (1,52 million Euros). These profits can be attributed to a high valuations titles and stocks and on profits from commissions of equity transactions during the best bull market of the last twenty years. Following a major correction of the Greek equity market in the first quarter of 2000, big banking institutions experienced a marginal decline in profitability growth over the first quarter of 1999. In 2000 the banking sector announced for the year 1999, mainly due to the increase of projects expected in the sector of retail banking, result of the constant reduction of the interest rates, in order for the levels of the rest of the countries participating in Exchange Rate Mechanism 2 (ERM 2) to converge. The intense activity observed in the internal banking market during the last two years, regarding mergers, redemptions and co-operations, hasn't stopped the rush of banking groups for expansion in the wider market of the Balkans, an area, which can give in the long run big development opportunities to powerful Greek banks.

In short, for years the Greek economy- and par excellence the Greek financial system was under the close ownership, management, and control of government. In the late 1990s, deregulation changed this situation. With a few exceptions, Greek banks are no longer under government ownership, management and control, and must compete the one against the other and against their European counterparts. This has created a wave of consolidation that raised market concentration. But how has it affected banking performance? 


\section{The Greek Banking In The Frame Of The Greek Financial Institutions}

Greek capital markets allocate credit on market terms, and while a sound business may have no problem with financing availability, interest rates range from 13 (prime rate) to 19 percent. Banks constitute the main source of financing. The derivatives market is still not important. The Athens Stock Exchange is increasingly used as a source of capital financing. The Greek government has initiated legislation to encourage a venture capital market. Capitalmarket growth has been hampered by the predominance of mall, family-owned firms, and the tendency either to invest in real estate and government bonds or to hold savings in bank deposits. Checks are predominately used for commercial transactions. Credit cards are widely available and used for retail transactions. Most of the liabilities of the commercial banks are in the form of savings deposits. The majority of bank loans are short- and medium- term; only one fifth of bank loans are long-term.

\section{DATA, METHODOLOGY AND STATISTICAL ANALYSIS}

In the study are investigated the degree of concentration and the performance of Greek banking and eventually their reciprocal dependence. The approach is performed with some appropriate statistical tools as financial and concentration ratios for the study of performance and correlation and multiple regression techniques for the determination of the functional connection between the banks profitability and some variables as equity, debt and expenses, which we consider as important for the banks profitability. Eventually, the data are submitted to the technique of Principal Components Analysis (PCA) in order to acquire a quick view of the similarities and the correlations in the data. The problem of interdependence between structure (concentration) and performance in the banking market has been extensively investigated in the framework of the structure conduct performance (SCP) hypothesis and its ramifications, in which heavy econometric models are used combining endogenous information and variables referring to the macroeconomic national and international environment of the banking sector, while for the study of concentration are used indices varying from simple, traditional ones (Gini's concentration ratio, for example) to complicated measures involving the statistical version of entropy. However, the volume and reliability of the available data do not permit to us the mobilisation of such refined tolls and limit ourselves in the use of the traditional ones.

For all calculations and graphs we have used the Excel and the STATISTICA packages. The complete list of data, details of calculations and the graphics are shown in the appended files to the present text. However, for an easy overview of the results, the main results are exhibited in tables in the text.

\section{The Data}

The data consist of excerpts of the balance sheets and profit and loss statements of several banks, but we included in our study only 31 banks for which the data are comparable for the years 1997 through 2004. However, the loss of information is not substantial, since the assets of the banks not included in the sample represent only a small percentage of the assets of the banks included in the data. All values in million Euro.

\section{Concentration And Pre-Tax Profit Ratios}

The market concentration is of great importance since it is an indication of the structure of the market and its ability to operate under free competition. There exist several indices for the measure of the market concentration, as the percentage of sales, profits, volume of assets or fixed capital, of equity etc., with which each particular unit participates to the market. Each index has its own merits and disadvantages. Unfortunately, one cannot use all of them since they are in the most of the cases contradictory. The choice depends on the specific purpose of the comparison and the nature of the economic unit. In our case we feel that the best concentration measures for the financial institutions is the size of equity. We avoided the use of indices such as total assets since the size of the balance sheet many times does not reflect the real position of the firm. Besides, indices relating to fixed assets are many times misleading: Some industries, for instance ship-yards or steel-works, have fixed assets of extremely high value, and yet they are weak organizations due to the obsoleteness of there products or to the high cost of production. We use the equity size as criterion of the branch concentration. For the calculation of the concentration ratio we use the $25 \%$ 
largest units. Further, The ratio Pre-tax profit / Equity is an important indication of the capacity of the financial sector to effectively use its overall long-term resources. We present in the table 1 below the values of the concentration ratio and the pre-tax profit index for the period 1997-2004.

Table 1: Financial ratios and pre-tax profit for the period 1997-2004

\begin{tabular}{|l|c|c|c|c|c|c|c|c|}
\hline & $\mathbf{1 9 9 7}$ & $\mathbf{1 9 9 8}$ & $\mathbf{1 9 9 9}$ & $\mathbf{2 0 0 0}$ & $\mathbf{2 0 0 1}$ & $\mathbf{2 0 0 2}$ & $\mathbf{2 0 0 3}$ & $\mathbf{2 0 0 4}$ \\
\hline Concentration ratio \% & 72,4 & 67,8 & 80,2 & 81,9 & 95,9 & 93,4 & 93,7 & 74,1 \\
\hline Pre-tax profit/ Equity \% & 9,6 & 5,0 & 6,6 & 0,8 & 0,4 & 0,2 & 0,5 & 4,6 \\
\hline
\end{tabular}

We comment the above results as follows: There exists a huge concentration in the Greek financial institutions system. Five of six banks control more than $70 \%$ of the whole market. This is an indication of monopolistic status in the market. It can explained by the fact that the most of these large banks were until ten or 15 years ago owned by the state, which did not permit the foundation of private banks unless of banks of unimportant size. So the market was conquered by a small number of state-owned banks. The results are reflected in the concentration indices. The concentration ratio in the years 2001-2003 takes extremely high, but in years 2004 it substantially declines. We can attribute this improvement to the deregulation of the Greek financial system and the privatisation of some important- at that time- banks working under either full state-owned status or under the immediate control from the side of the government. Some more comments on this issue are given in the section of conclusions.

\section{Correlation Analysis}

The purpose of submitting the data to correlation analysis is to get insight into the correlation between the variables, taken in pairs, in order to conclude if there exists co-linearity between the variables, as measured by the coefficient of correlation. Since in the purposes of the study is the identification of determining factors of the banks performance, the correlation analysis can be a first step to detecting strong inter-relations between the variables involved. The interest, of coarse, is focused in the correlation between the pre-tax profit, as indicator of the banks performance, and each of the rest of the balance sheet and profit and loss statement items. Further, a correlation value between two variables near to the borders of the variation range of the coefficient of correlation ( -1 to 1$)$ is an indication that the simple regression of one of the variables to the other will give significant b-coefficient (the coefficient of the independent variable), which in turn permits good predictions of the value of the one variable, considered as dependent variable, in terms of the other. Also, in case of co-linearity between homogeneous variables one can replace the co-linear variables by an aggregate of them and this way to reduce the number of the variables involved. The matrices of correlation are exhibited in the STATISTICA files CORR1997 through CORR2004. For easy reference we recapitulate the correlations as follows:

\section{Pre-tax profit}

- Positively correlated with the Equity in the years 1997, 1998, 1999, and 2004 and negatively in 2000,2001, 2002 and 2003.

- $\quad$ Positively correlated with the Debt in the years 1998, 2000, 2001, 2002, 2003 and 2004 and negatively in 1997 and 1999.

- $\quad$ Positively correlated with the Expenses in the years 2002, 2003 and negatively in 1997, 1998, 1999, 2000, 2001, 2004.

\section{Equity}

- $\quad$ Positively correlated with the Debt in all years under consideration unless in year 2001.

- $\quad$ Negatively correlated with Expenses in all years. 
Debt

- $\quad$ Negatively correlated with Expenses in all years.

\section{Regression Analysis}

In this part of the analysis we test the hypothesis that the main factor for the profits level is the bank's size. But size is no uniquely defined measure. The assets volume, the equity's size, the volume of sales, the working capital, the volume of customers' deposits etc. can equally be considered as measure of the bank's size. No item from the above mentioned ones can one-way determine the bank's size but on the other side one cannot neglect these parameters when he wants to determine the bank's size. Hence, one has to create a composite variable, an aggregate in which all of the above items are reflected. In this investigation we will work on the assumption that the bank's profit is mainly affected by the size, as a combination of the equity, the bank's borrowings from customers (deposits) and other financial institutions and the operating expenses. A notice is necessary here: The firm's profitability and performance is usually measured by indices such as Returns On Equity (ROE), Returns On Assets (ROA), liquidity ratios, solvency ratios etc. However, although the informational content of these ratios are of extreme importance in appraising the firm' performance, we have avoided the use of such parameters for the reason that these parameters, being quotients, usually violate the assumptions of the least squares method. Besides, given the small size of our sample we found it necessary to reduce the number of independent variables to a small number of candidate variables and relay them to the dependent variable, the pre-tax profit. The variables chosen as independent are Equity, Debt and Expenses. According to the above approach the multiple regression model for the banks profitability takes the following form:

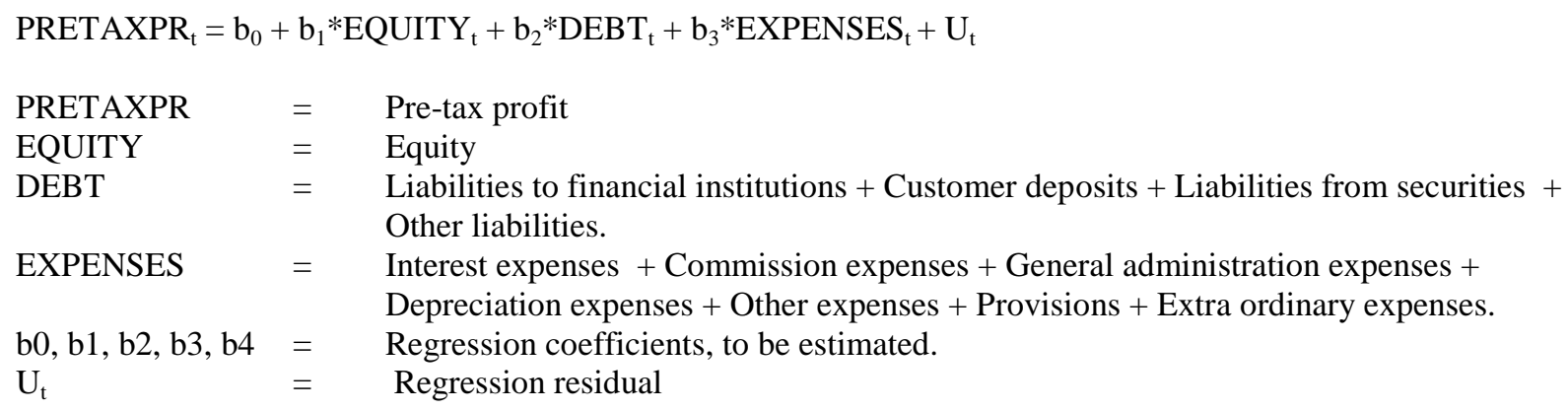

For the estimation of the regression coefficients we have applied the method of the ordinary least squares (OLS). We have performed the regression analysis for each year from 1997 through 2004. The estimates of the regression coefficients are followed by examination of the degree of deviation from normality in the data. For detecting autocorrelation between the measurements we use the Durbin-Watson d-statistic. The detailed regression results are exhibited in tabular form in the regression summaries in the STATISTICA files. For easy reference we present the regression results in the following table 2 (In parenthesis below estimates is figuring the p-level. The highlighted parameters estimates are significant at level of significance 5\% under the two-tailed t-test). 
Table 2: Regression Parameters Estimates

\begin{tabular}{|c|c|c|c|c|c|c|}
\hline Year & $\begin{array}{c}\text { b0 } \\
\text { (Intercept) }\end{array}$ & $\begin{array}{c}\text { b1 } \\
\text { (EQUITY) }\end{array}$ & $\begin{array}{c}\mathbf{b 2} \\
(\mathrm{DEBT})\end{array}$ & $\begin{array}{c}\text { b3 } \\
\text { (EXPENSES) }\end{array}$ & P-level for F-test & $\begin{array}{c}\text { Adjusted Coefficient of } \\
\text { determination } \mathbf{R}^{2}\end{array}$ \\
\hline 1997 & $\begin{array}{c}-173,581 \\
(0,394) \\
\end{array}$ & $\begin{array}{c}1,089 \\
(0,007) \\
\end{array}$ & $\begin{array}{l}-0,340 \\
(0,001)\end{array}$ & $\begin{array}{l}-2.375 \\
(0,004) \\
\end{array}$ & 0,001 & 0,649 \\
\hline 1998 & $\begin{array}{c}3,043493 \\
(0,912)\end{array}$ & $\begin{array}{c}0,043576 \\
(0,297)\end{array}$ & $\begin{array}{c}0,01834 \\
(0,110) \\
\end{array}$ & $\begin{array}{c}0,148777 \\
(0,120)\end{array}$ & 0,304 & 0,065 \\
\hline 1999 & $\begin{array}{c}-37,7600 \\
(0,163) \\
\end{array}$ & $\begin{array}{l}0,0958 \\
(0,000)\end{array}$ & $\begin{array}{l}0,0303 \\
(0,079) \\
\end{array}$ & $\begin{array}{l}0,2784 \\
(0,057) \\
\end{array}$ & 0,000 & 0,927 \\
\hline 2000 & $\begin{array}{c}8,647346 \\
(0,686)\end{array}$ & $\begin{array}{c}-0,014118 \\
(0,002)\end{array}$ & $\begin{array}{c}0,00908 \\
(0,211)\end{array}$ & $\begin{array}{c}0,037726 \\
(0,557)\end{array}$ & 0,001 & 0,488 \\
\hline 2001 & $\begin{array}{c}0,709361 \\
(0,967)\end{array}$ & $\begin{array}{c}0,001096 \\
(0,538)\end{array}$ & $\begin{array}{c}0,00892 \\
(0,227)\end{array}$ & $\begin{array}{c}0,062839 \\
(0,515)\end{array}$ & 0,068 & 0,187 \\
\hline 2002 & $\begin{array}{c}0,538423 \\
(0,970) \\
\end{array}$ & $\begin{array}{c}0,035415 \\
(0,257) \\
\end{array}$ & $\begin{array}{c}0,00210 \\
(0,105) \\
\end{array}$ & $\begin{array}{c}0,041762 \\
(0,215) \\
\end{array}$ & 0,000 & 0,434 \\
\hline 2003 & $\begin{array}{c}4,714513 \\
(0,762)\end{array}$ & $\begin{array}{c}-0,000049 \\
(0,990)\end{array}$ & $\begin{array}{c}0,00384 \\
(0,041)\end{array}$ & $\begin{array}{c}0,006874 \\
(0,714)\end{array}$ & 0,150 & 0,090 \\
\hline 2004 & $\begin{array}{c}-21,7426 \\
(0,484)\end{array}$ & $\begin{array}{l}0,1688 \\
(0,015)\end{array}$ & $\begin{array}{r}-0,0019 \\
(0,838)\end{array}$ & $\begin{array}{l}0,1232 \\
(0,391)\end{array}$ & 0,055 & 0,299 \\
\hline
\end{tabular}

In the above table we read that

$1 /$ In respect to the Student's t-test

-In all years the value of intercept is not significant

-The coefficient of Equity is significant in only three years out of eight $(1997,1999,2000)$

-The coefficient of Debt is significant in only two years out of eight $(1997,2003)$

-The coefficient of Expenses is significant only in 1997.

2/ The F-test, which checks the simultaneous nullity of all regression parameters rejects the null-hypothesis (all parameters are zero) for the years 1997, 1999, 2000, 2000, while it does not reject the hypothesis in the rest of the years.

\section{Analysis Of Deviations From Normality-Normal Plot Of Residuals}

Multiple regression analysis assumes that the residual values (observed minus predicted values) are normally distributed, and that the regression function (the relationship between the independent and dependent variables) is linear in nature. If any of these assumptions is grossly violated, then the regression coefficients (b-coefficients) may be affected (inflated or deflated), and the statistical significance tests inflated or deflated. If "all is well," one can expect the residual values to be normally distributed. Normal probability plots provide a quick way to visually inspect to what extent the pattern of residuals follows a normal distribution. If the residuals are not normally distributed, they will deviate from the line. Outliers may also become evident in this plot. If there is a general lack of fit, and the data seem to form a clear pattern (e.g., an S shape) around the line, this is a sign of lack of normality in the data. This is the case in our data as it is clearly shown in the graphics "Normal Probability Plot of residuals" for all the years 1997 through 2004 (Graphs GR-NPPR1997 through GR-NPPR2004).

\section{Analysis Of Autocorrelation - Durbin-Watson D-Statistic}

The Durbin-Watson d-statistic is used for evaluating the presence or absence of a serial correlation of residuals (i.e., whether or not residuals for adjacent cases are correlated, indicating that the observations or cases in the data file are not independent). All statistical significance tests in multiple regression analysis assume that the data consist of a random sample of independent observations. If this is not the case, then the estimates (b coefficients) may be less stable than the significance levels would assume. Under the null hypothesis that there is no autocorrelation in the data $(\rho=0)$, the found estimate $r$ of $\rho$ should be included between two limits (given from tables). If $r$ fails to do so, then the null hypothesis is rejected in favor of the alternative hypothesis that there is autocorrelation between the data. In our cases the number of independent variables is 3 .

In the table 3 below are shown the lower and upper limits $d_{L}$ and $d_{U}$ at $5 \%$ significant level. (STATISTICA files DW1997 through DW2004). 
Table 3: Durbin-Watson d-statistics for the period 1997-2004

\begin{tabular}{|l|c|c|c|c|c|c|c|c|}
\hline & $\mathbf{1 9 9 7}$ & $\mathbf{1 9 9 8}$ & $\mathbf{1 9 9 9}$ & $\mathbf{2 0 0 0}$ & $\mathbf{2 0 0 1}$ & $\mathbf{2 0 0 2}$ & $\mathbf{2 0 0 3}$ & $\mathbf{2 0 0 4}$ \\
\hline $\begin{array}{l}\text { DW d- } \\
\text { statist. }\end{array}$ & 2,201 & 1,369 & 0,976 & 1,372 & 1,276 & 1,341 & 1,308 & 1,016 \\
$(0,86-1,73)$ & $(0,86-1,73)$ & $(1,05-1,66)$ & $(1,05-1,66)$ & $(1,10-1,66)$ & $(1,18-1,65)$ & $(1,20-1,65)$ & $(0,90-1,71)$ \\
\hline $\begin{array}{l}\text { Serial } \\
\text { correl. }\end{array}$ & $-0,119$ & $-0,007$ & 0,337 & 0,022 & 0,058 & 0,081 & 0,015 & 0,249 \\
\hline
\end{tabular}

As we can see in the above table there is no significant autocorrelation in the regression residuals, except in the years 1997 and 1999.

\section{Principal Components Analysis}

The correlation analysis, however necessary and important, is subject to two great disadvantages: First, the correlated variable must be considered in pairs, which doesn't provide any insight into the correlation of the variables considered together. Second, it doesn't provide any information about the profile for variables tabulated in matrix form, as it is our case. To overcome these disadvantages, the principal components analysis (PCA) was deployed as a supplementary and/or alternative method for quick, simple and comprehensive treatment of the data.

The result of the principal components analysis for each year separately are summarized the appropriate STATISTICA graphs. The graphs of variables (loadings) are the graphs GR-PCA1997 through GR-PCA2004. We do not give details of the interpretation of the results in the factorial axes, for this would require a special study. We mention only the most important principles of the results interpretation on the factorial plane:

- $\quad$ The greater the total explained variance from the factorial axes, as expressed by the proper value corresponding to the axis- proper vector, the better the descriptive power of the method.

- $\quad$ Each variable is represented in the factorial plane as a point.

- $\quad$ The variables close to a factorial axis and remote from the origin exhibits strong correlation (loading in the terminology of this method) with the factorial axis, i.e. with the rest of the variables.

- $\quad$ The variables near to each other are correlated in the same with the rest of the variables.

The same is true for the interpretation in the factorial pane of the profile of the banks (individuals or cases in the PCA terminology).

Table 4 provides the cumulative percentage of the proper values (eigenvalues) of the first two factorial axes. The higher the value of this percentage, the largest the portion of variability explained by the first two axes; and the better the suitability of the method.

Table 4: Cumulative Percentage Of The Proper Values Corresponding To The First Two Factorial Axes Of The Principal Components Analysis. Items (banks) strongly correlated with the rest of the items.

\begin{tabular}{|c|c|c|c|c|c|c|c|c|}
\hline & 1997 & 1998 & 1999 & 2000 & 2001 & 2002 & 2003 & 2004 \\
\hline$\left(\lambda_{1}+\lambda_{2}\right) / \Sigma \lambda_{1} \%$ & 91,77 & 84,65 & 98,62 & 92,25 & 85,66 & 90,23 & 87,63 & 97,20 \\
\hline INV $=$ Bank of Investments & $\checkmark$ & & $\sqrt{ }$ & $\sqrt{ }$ & $\sqrt{ }$ & $\sqrt{ }$ & $\sqrt{ }$ & \\
\hline $\mathrm{AGR}=$ Agricultural Bank & $\checkmark$ & $\checkmark$ & $\checkmark$ & & & & & \\
\hline $\mathrm{ALPH}=$ Alpha Bank & $\sqrt{ }$ & $\checkmark$ & $\sqrt{ }$ & $\checkmark$ & $\sqrt{ }$ & $\sqrt{ }$ & & $\checkmark$ \\
\hline NAT $=$ National Bank of Greece & $\sqrt{ }$ & $\checkmark$ & $\sqrt{ }$ & $\checkmark$ & $\sqrt{ }$ & $\sqrt{ }$ & $\sqrt{ }$ & $\sqrt{ }$ \\
\hline POST=Post Bank & $\sqrt{ }$ & & & & & & & \\
\hline $\mathrm{EFG}=\mathrm{EFG}$ Eurobank & & & & & & & & $\sqrt{ }$ \\
\hline
\end{tabular}


The very high values of the proper values indicate that the projection of the items (banks) onto the factorial plane is reliable and, therefore, the correlations between the items are reliable reflected by the relative position of the items. Further, the graph isolates the banks strongly correlated with the rest of the banks. A search through the balance sheet of these banks shows that this strong correlation is caused by their large size.

\section{CONCLUSION}

Summarizing the results of the investigation concerning the relation between degree of concentration in the banking sector and performance it seems that the pre-tax profit is only partly explained by the variables which we considered as relevant. The concentration and the performance analysis reveal intrinsic weaknesses of the Greek financial institutions: Low degree of performance and competitiveness as it is indicated by the extra-ordinary high degree of concentration.

However, in our statistical investigation important parameters as the prevailing situation in the financial market as a whole, the national and the international economic conjuncture are not taken into consideration. But these parameters are closely related with the concentration and performance of the banks. In addition comes, that in our case the application of the ordinary regression methods, do not always result to significant estimates of the regression.

It is difficult to decide if the regression results obtained in our investigation are accidental or they are due to incomplete statistical treatment of the data. In any case, however, the statistics alone cannot prove or disprove any theory. This is the task of the specialist, who employs statistical methods to measure to describe, correlate and forecast. In this sense the statistics is an indispensable tool for his job but not the decisive one. We believe that in cases that theory and statistical evidence do not tally, it is the theory the factor that should have the last word. Certainly, the collection or more data and the application of more sophisticated methods can enlighten more the subject.

\section{BIBLIOGRAPHY}

1. $\quad$ Aivazian, S. 1970, Etude Statistique des Dependences, Moscow: Mir Publishers.

2. Allen, L. and Rai, A. 1996, Operational Efficiency in Banking: An International Comparison. Journal of Banking and Finance. May, pp. 655-672.

3. Altunbas, Y., Gardener, E.P.M., Molyneux, P. and Moore, B. 1999, Efficiency in European Banking. IEF Working Paper. Institute of European Finance. University of Wales, Bangor.

4. Altunbas, Y., Molyneux, P. and Thornton, J. 1997, Big Bank Mergers in Europe- An analysis of the cost implications. Economica, 64, pp. 317-29.

5. $\quad$ Arkin, H. and Colton R. 1964, Statistical Methods, New York: Barnes \& Noble.

6. Berger, A.N. 1995, The profit-structure relationship in banking - tests of market power and efficient structure hypothesis. Journal of Money. Credit and Banking, 27(2), pp. 404-431.

7. Berger, A. N. and Hannan, T. H. The Price-concentration Relationship in Banking. The Review of Economics and Statistics. vol. 71. May 1989, pp. 291-299.

8. Berger, A.N. and Humphrey, D. (1997). Efficiency of financial institutions: International survey and directions for future research. European Journal of Operations Research, 98, pp. 175-212.

9. Berger, A.N. and Mester, L.J. 1997, Inside the black box: What explains differences in the efficiencies of financial institutions. Journal of Banking and Finance, 21, (7), pp. 895-947.

10. Blume, M. 1975, Betas and the Regression Tendencies, Journal of Finance, vol. 30, pp. 785-95.

11. Bouroche, J. M. and Saporta G. 1975, L' Analyse des Donnees, Paris: Presses Universitaires De France.

12. Brailsford, T., Faff, R and Oliver, B. 1997, Research Design Issues in the Estimation of Beta, McGraw-Hill series in advanced finance.

13. Corhay, A. 1992, The Intervaling-Effect Bias in Beta; A Note, Journal of Banking and Finance, vol. 16, pp. 61-73. 
14. De Bandt, O. and Davis, E.P. 1998, Competition, Contestability and Market Structure in European banking Sectors on the Eve of EMU - Evidence from France, Germany, and Italy with a Perspective on the United States. Paper presented at the T or Vergata Financial Conference on Post-Euro Competition and Strategy among Financial Systems and Bank-Firm Relations. Rome, 26-27 November.

15. Gardener, E.P.M. and Molyneux, P. (1997). The too-big-to-fail doctrine revisited EIB Papers, 2 (1), pp. 1532.

16. Gilbert, R.A 1984, Bank market structure and competition - a survey. Journal of Money, Credit and Banking, 16 (4), part 2, pp. 617-645, November.

17. Gurley, J. and Shaw, E. Financial Aspects of Economic Development. American Economic Review, 1955, 45.

18. Hannan, T. H. Bank Commercial Loan Markets and the Role of Market Structure: Evidence from Surveys of Commercial Lending. Journal of Banking and Finance, vol. 15. February 1991, pp 133-149.

19. Huang, D. S. 1969, Regression and Econometric Methods, New York: John Wiley \& Sons.

20. John, D. C. Gramm-Leach-Bliley Act (S.900): A Major Step Toward Financial Deregulation. The Heritage Foundation Backgrounder. 28 Oct 1999.

21. Johnson, R. A. and Wichern D. W. 1998, Applied Multivariate Statistical Analysis, New Jersey: Prentice Hall.

22. Kane, E. J. Incentives For Bank Megamergers: What motives might regulators infer from Event-Study Evidence? Journal of Money, Credit and Banking vol 32. August 2000. pp. 671-705: Ohio State University Press, Columbus, Ohio.

23. Kaserman, D. L. and Mayo, J. W. 1995, Government and Business. The Economics of Antitrust and Regulation. The Dryden Press. Orlando, Fla: 1995.

24. Kroszner, R. S. The Motivations Behind Banking Reform. Regulation. Summer 2001. pp 36-41.

25. Lebart L. and Fenelon J. P. 1973, Statistique et Informatique Aplliquees, Paris: Dunod.

26. Lehn, J. and Wegmann, H. 1992, Einfuerung in die Statistik, Stuttgart: Teubner.

27. Mishkin, F. The Economics of Money, Banking and Financial Market. Addison- Wesley, 1997.

28. Molyneux, P. 1995, Cooperation and rivalry in banking markets, Chapter 1 in Research in International Business and Finance. Vol.12. J.Doukas and L.Lang (eds), pp. 3-23.

29. Molyneux, P., Altunbas, Y. and Gardener E.P.M. 1996, Efficiency in European Banking, Wiley; London.

30. Molyneux, P. and Shamroukh, N. 1999, Financial Innovation, Wiley: London.

31. Molyneux, P. and Shamroukh, N. 1996, Diffusion of Financial Innovations - The Case of High Yield Debt and Note Issuance Facilities. Journal of Money, Credit and Banking, August, 28, 3, Pt2, pp. 502-522.

32. Neumark, D. and Sharpe, S. A. Market Structure and the Nature of Price Rigidity: Evidence from the Market for Consumer Deposits. Quarterly Journal of Economics, vol.107, no.2, pp 657-680.

33. Revell, J. 1987, Mergers and the role of large banks. IEF Monograph, 2. Institute of European Finance, University of Wales, Bangor IEF:Bangor.

34. Simons, Katerina, and Stavins, Joanna. Has Antitrust Policy in Banking Become Obsolete? New England Economic Review. March/April 1998. pp 13-26.

35. Theil, H. 1970, Principles of Econometrics, New York: John Wiley \& Sons.

36. Vander, V. R. 1998, Cost and Profit Dynamics in Financial Conglomerates and Universal banks in Europe. Paper presented for the SUERF/CFS Colloquim, Frankfurt, 15-17 October 1998.

37. Vander, V. R. 1996, The effect of mergers and acquisitions on the efficiency and profitability of EC credit institutions. Journal of Banking and Finance, November, pp. 1531-1558. 